\title{
Translator's Note
}

In transcribing Hebrew letters, names, and words, diacritical marks have been omitted, both in keeping with common practice in many English-language lexicons on Judaism and for greater readability; the transcription is phonetic. Transcribed Hebrew terms appear in italics, with the exception of those that are so commonly used they are no longer considered foreign words, such as Sabbath, Kabbalah, and Torah. The names of Hebrew-language authors are spelled as they most often occur in English-language sources. Hebrew book titles in the bibliography are followed by English translations in square brackets. The spelling of Yiddish words is based on Ronald Lötzsch, Jiddisches Wörterbuch, 2nd ed. (Mannheim: Bibliographisches Institut, 1992).

Unless otherwise noted, Bible passages are cited from The New English Bible with the Apocrypha (New York: Oxford University Press, 1971). Biblical names are spelled as they appear in this edition. Passages from the Babylonian Talmud (BT), Mishnah, and other rabbinical texts with the exception of the Jerusalem Talmud are taken from the Sefaria and Chabad websites. The names of rabbinical texts are spelled as they appear on these websites. Passages from the Jerusalem Talmud (JT), if not otherwise noted, have been translated by the author. Dead Sea Scrolls passages are taken from Die Texte aus Qumran (1986; 2001); see bibliography.

A number of the German and Yiddish texts cited are available in English translation; in those cases, the existing translation was used, and the English title appears in the bibliography. For works unavailable in English, the original titles appear in the bibliography, and the translations, unless otherwise noted, are my own. 
